\title{
OPEN New chalcone derivatives as potential antimicrobial and antioxidant agent
}

\author{
Emelda N. Okolo ${ }^{1}$, David I. Ugwu ${ }^{1 凶}$, Benjamin E. Ezema ${ }^{1}$, Joseph C. Ndefo ${ }^{2}$, \\ Florence U. Eze ${ }^{1}$, Chidimma G. Ezema ${ }^{3}$, James A. Ezugwu ${ }^{1}$ \& Oguejiofo T. Ujam ${ }^{1}$
}

Seven chalcone derivatives were synthesized by the Claisen-Schmidt condensation. The structures of the compounds were confirmed by spectral data (Ultraviolet/visible, infrared, nuclear magnetic resonance and mass spectroscopy). The compounds were tested for their in silico and in vitro antimicrobial and antioxidant activities. The molecular docking assessments showed that all the compounds exhibited good binding affinity with the target microorganism proteins but, compounds $6 e$ and $6 \mathrm{~g}$ showed better binding affinity compared with the standards. The antimicrobial test revealed that all the compounds screened were active against Staphylococcus aureus and Bacillus subtilis and had minimum inhibitory concentrations (MIC) between 0.4 and $0.6 \mathrm{mg} / \mathrm{mL}$. Compounds $6 \mathrm{a}, 6 \mathrm{c}$ and $6 \mathrm{~d}$ had moderate activities on Salmonella typhi. Compounds $6 \mathrm{~b}$ and $6 \mathrm{c}$ had moderate activity on Escherichia coli. Compound $6 \mathrm{c}$ had moderate activity on Aspergillus niger while compounds $6 \mathrm{a}$ and $6 \mathrm{e}$ had poor activity. All the compounds except compound $6 \mathrm{e}$ had no inhibition against Pseudomonas aeruginosa. The in-vitro antioxidant activity was assessed using ethylenediaminetetraacetate (EDTA) as the standard. Compounds $6 \mathrm{c}, 6 \mathrm{e}$ and $6 \mathrm{~g}$ gave excellent inhibitory activity better than the standard. Compound 6 a gave good activity at $500 \mu \mathrm{g} / \mathrm{mL}$ and $1000 \mu \mathrm{g} / \mathrm{mL}$ concentrations but, below the standard at $250 \mu \mathrm{g} / \mathrm{mL}$ and no inhibition at $125 \mu \mathrm{g} / \mathrm{mL}$. Compound $6 \mathrm{~d}$ had good inhibition at $500 \mu \mathrm{g} /$ $\mathrm{mL}$ and $1000 \mu \mathrm{g} / \mathrm{mL}$ but, no inhibition at $125 \mu \mathrm{g} / \mathrm{mL}$ and $250 \mu \mathrm{g} / \mathrm{mL}$. Compound $6 \mathrm{~b}$ was found to be inactive in all the concentrations. Absorption, distribution, metabolism and excretion properties of the compounds were assessed using SwissADME. The results of lead likeness showed that compound 6e is a lead-like molecule.

The success recorded in the treatment of infectious diseases is consistently challenged by continues report of bacterial resistance. The mechanism of resistance is usually encoded genetically and as such can be transferable ${ }^{1}$. This wide increase in resistance mechanism negatively affects the therapeutic efficacy of a whole class of drugs ${ }^{2}$.

Oxidative stress is implicated in many human diseases ${ }^{3}$. Elevation of superoxide anions, hydrogen peroxide, hydroxyl, nitric oxide and peroxynitrite causes damage to many cellular macromolecules including DNA ${ }^{4,5}$. These damages often leads to diabetes, atherosclerosis, myocardial infarction, damage may result into many diseases including diabetes mellitus, atherosclerosis, mycocardial infarction, arthritis, anemia, asthma, inflammation and many more ${ }^{6}$. However, human cells uses superoxide dismutase, catalase, glutathione reductase, ascorbic acid and other enzymatic and non-enzymatic mechanism to stop the production of free radicals ${ }^{7}$. The protective role of these enzymes are often times disrupted during pathological processes thereby necessitating the use of antioxidant supplements or drugs. The reported human and animal toxicity to many antioxidants like butylated hydroxyanisole (BHA), butylated hydroxytoluene (BHT) and acidity of ascorbic acid prompted the search for new antioxidants ${ }^{8}$.

Chalcones are structural derivatives of 1,3-diphenylprop-2-en-1-one. They are ubiquitous in natural products and belong to the family of flavonoids examples licochalcone A (1) licochalcone D (2) and morachalcone A $(3)^{9,10}$. They have been reportedly used as anticancer ${ }^{11,12}$, antidiabetics ${ }^{13}$, antioxidants ${ }^{14}$, antimalarial ${ }^{15,16}$, antitubercular ${ }^{17,18}$, antiviral ${ }^{19}$, anti-inflammatory ${ }^{20,21}$, antibacterial ${ }^{22,23}$ agents etc. Furthermore, chalcones are industrially used as light stabilizing agent ${ }^{24}$, sweetening agent ${ }^{25}$, analytical reagent in amperometry ${ }^{26}$, spectrometric reagent ${ }^{27}$ and synthetic reagent for the synthesis of pharmacologically active heterocyclic compounds ${ }^{28-30}$.

${ }^{1}$ Department of Pure and Industrial Chemistry, University of Nigeria, Nsukka, Nigeria. ${ }^{2}$ Department of Science Laboratory Technology, University of Nigeria, Nsukka, Nigeria. ${ }^{3}$ National Center for Energy Research and Development, University of Nigeria, Nsukka, Nigeria. ${ }^{\circledR}$ email: izuchukwu.ugwu@unn.edu.ng 
<smiles>C=CC(C)(C)c1cc(/C=C/C(=O)c2ccc(O)cc2)c(O)cc1O</smiles>

1<smiles>COc1c(/C=C/C(=O)c2ccc(O)c(CC=C(C)C)c2)ccc(O)c1O</smiles>

2

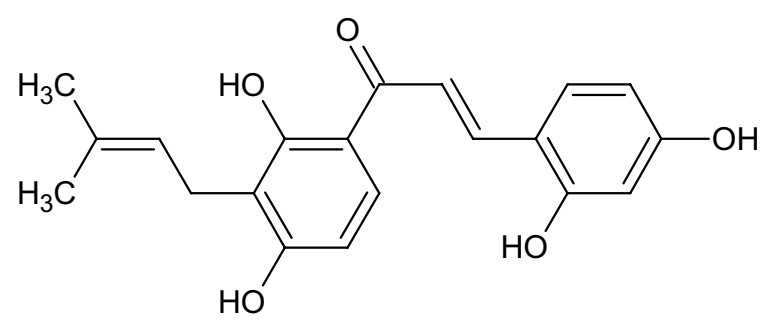

3

The immediate response of antigen is the Reactive-Oxygen Species (ROS) appearance in the body during microbial invaders. Free oxygen radicals are very toxic to pathogen and are used as agent to prevent attack of tissues by microorganism ${ }^{31}$.

Oxidative stress is seen as the main factor concerned with the development of chronic diseases and it happens when oxygen radical production and levels are higher than those of the antioxidant ${ }^{32}$. The importance of ROS for immune function could be used by the microbes to reduce defense mechanism of the host to survive. One of the important characteristic of plants accountable for antioxidant activity is the presence of derivatives of phenol and the power to hunt free radicals which can act as immunity against the harmful action of ROS. So antagonizing the production of ROS and free radical by addition of antioxidants can play important function in averting these free radical related diseases ${ }^{33}$.

Chalcones have preventive effects against many microorganisms. The antimicrobial effects are due to reactions between these compounds and the cell membrane of the target microorganism, their ability to attach with outer cell, absorbable proteins and the cell walls ${ }^{34}$. It is therefore possible to think that chalcones could inhibit the microbes through their antioxidant properties.

Glucosamine-6-phosphate synthase is responsible for the metabolism of hexosamine, an important process in the biosynthesis of amino sugars needed for cell growth and development. UDP-3-O- $(R)-3$-hydroxymyristoyl)$\mathrm{N}$-acetylglucosamine deacetylase is involved in the biosynthesis of lipid A, a phosphorylated glycolipid that anchors the lipopolysaccharide to the outer membrane of the cell ${ }^{35}$. DNA gyrase is involved in the control of topological transition of DNA, thereby promoting replication and transcription ${ }^{36}$. Urate oxidase catalyse the oxidation of uric acid to allantoin and the inhibition of this enzyme leads to accumulation of toxic uric acid in the microorganisms. Dihydrofolate reductase is an important enzyme in the conversion of pteridine to folic acid required by all cells for growth and development. Given the roles of these enzymes in the growth and development of organisms, their successful inhibition have been characterized as therapeutic target for drug development research.

This work was designed based on the reported pharmacological application of chalcones and the need for an antimicrobial host to have some antioxidant abilities to attack the reactive oxygen species produced by microorganism.

We herein report the synthesis of some new chalcones with good antimicrobial and antioxidant activities.

\section{Materials and methods}

The chemicals used for experimental were of analytical grade purchased from Sigma-Aldrich and used it without purification. Melting points were determined using Fischer John's melting point apparatus and were not corrected. UV-Visible spectra were recorded on UV5800PC series spectrophotometer using matched $1 \mathrm{~cm}$ quartz cells. The IR spectra were recorded on Buck Scientific m910 FTIR U S A using KBr discs. Jeol $400 \mathrm{MHz}$ was used for NMR whereas Waters Q-TOF premier HAB213 was used for Mass spectroscopy.

\section{Experimental}

Synthesis of chalcone derivatives. Acetophenone (4) (0.01 mol) and substituted benzaldehyde (5) $(0 \mathrm{~L} .01 \mathrm{~mol})$ were mixed in a round bottom flask. Ethanol $(30 \mathrm{~mL})$ was annexed and then $40 \%$ potassium hydroxide $(15 \mathrm{~mL})$. The mixture was stirred for $30 \mathrm{~min}$ at room temperature, then left to stand for $24 \mathrm{~h}$. The mixture was poured into a beaker containing crushed ice to quench the reaction and then neutralized with $10 \% \mathrm{HCl}$. The precipitates formed were filtered, washed with distilled water and dried. They were then recrystallized from absolute ethanol to obtain the desired products (6-12). 
(2E)-3-(3-nitrophenyl)-1-phenylprop-2-en-1-one (6). Yield $=87 \%, \quad \mathrm{~m} . \mathrm{p}=107-109{ }^{\circ} \mathrm{C}$, UV-visible (EtOH) $\lambda \max (\mathrm{nm}) \log (\varepsilon): 252$ (2.852), $314(2.6114), 360(2.5375), \mathrm{IR}(\mathrm{KBr}) \mathrm{v} ; 3801(2 \mathrm{v},(\mathrm{C}=\mathrm{O}), \mathrm{s}$-trans), $3695(2 \mathrm{v},(\mathrm{C}=\mathrm{O})$, $\mathrm{s}$-cis), 3178 (C-H stretch), 1850 ( $\mathrm{v}(\mathrm{C}=\mathrm{O})$ stretch), 1601 ( $\mathrm{C}=\mathrm{C}$ stretch), 1393 (C-H bending), 1184 (C-N stretch). ${ }^{1} \mathrm{HNMR}\left(400 \mathrm{MHz}, \mathrm{CDCl}_{3}\right.$ ) $): 8.505-8.496(\mathrm{~m}, 1 \mathrm{H}, \mathrm{ArH}), 8.258-8.234(\mathrm{~m}, 2 \mathrm{H}, \mathrm{ArH}), 8.111-8.029(\mathrm{~m}, 2 \mathrm{H}$, ArH), 7.91 (d, J = 7.2 Hz, 1H,ArH), 7.843-7.803 (m, 1H, ArH),7.634-7.586 (m, 2H, ArH), 7.524-7.450 (m, 2H, ArH), 7.249-7.203 (m,1H, ArH) ${ }^{13} \mathrm{CNMR}\left(400 \mathrm{MHz}, \mathrm{CDCl}_{3} \delta\right): 189.825$ (C=O of ketone), 148.808, 141.771, $137.643,136.727,134.458,133.438,130.158,128.909,128.709,128.575,124.771,124.685,122.444$, (13 aromatic carbon). ESI-MS: (m/z) M+253.1354.

(2E)-3-(4-chlorophenyl)-1-phenylprop-2-en-1-one (7). Yield $=82 \%, \mathrm{mp}: 204-206{ }^{\circ} \mathrm{C}$, UV-visible (EtOH) $\lambda \max$ $(\mathrm{nm}) \log (\varepsilon), 248$ (2.6356), $290(2.4651), 636(0.2022)$. IR (KBr) v: $3806(2 \mathrm{v},(\mathrm{C}=\mathrm{O})$, S-trans), $3700(2 \mathrm{v},(\mathrm{C}=\mathrm{O})$, s-cis), 3219 (C-H stretch), 1817 ( $\mathrm{v}(\mathrm{C}=\mathrm{O})$ stretch, 1616 (C=C stretch), 821 (C-Cl stretch). ${ }^{1} \mathrm{HN} \mathrm{MR}(400 \mathrm{MHz}$, DMSO, $\delta): ~ 8.304$ (m, 1H, ArH), 8.171-8.149 (m, 2H, ArH), 7.997-7.982, 7.99 (d, 5.96 Hz, 1H, ArH), 7.7147.691, 7.70 (d, 9, 2 Hz, 2H, ArH), 7.113-7.052 (m,5H, ArH), 6.867 (m, 1H, ArH), 6.383-6.364 (m,1H, ArH) ${ }^{13} \mathrm{CNMR}(400 \mathrm{MHz}, \mathrm{DMSO}, \delta): 195.584(\mathrm{C}=\mathrm{O}), 153.472,149.924,149.552,147.224,137.877,131.057,129.416$, 128.720, 125.820, 124.762, 124.504, 113.411. ESI-MS: (m/z) M+242.0495.

(2E)-3-(3, 4-dimethoxyphenyl)-1-phenylprop-2-en-1-one (8). Yield 76\% mp. 72-74 ${ }^{\circ} \mathrm{C} \mathrm{UV}$-visible (EtOH) $\lambda \max$ $(\mathrm{nm}) \log (\varepsilon): 246$ (2.4338), 294 (2.2628), 404 (2.4761). IR (KBr)v: 3796 (2v, (C=O), s-trans), $3488(2 \mathrm{v},(\mathrm{C}=\mathrm{O})$, s-cis), 3058 (C-H stretch), $1870\left(\mathrm{v}(\mathrm{C}=\mathrm{O})\right.$ stretch), 1616 ( $\mathrm{C}=\mathrm{C}$ stretch), 1430 (C-H bending), ${ }^{1} \mathrm{HNMR}(400 \mathrm{MHz}$, $\left.\mathrm{CDCl}_{3}, \delta\right): 8.011-7.925$ (m, 1H, ArH), 7.786-7.687 (m, 1H, ArH), 7.588-7.360 (m, 3H, ArH), 7.301-7.151 (m, 2H, ArH), 7.125-6.983 (m, 1H, ArH), 6.902-6.721 (m, 1H, ArH), 6.681-6.551 (m, 1H, ArH), 3.942 (s, 3H, $\left.\mathrm{CH}_{3}\right), 3.806\left(\mathrm{~s}, 3 \mathrm{H},-\mathrm{CH}_{3}\right){ }^{13} \mathrm{CNMR}\left(400 \mathrm{MHz}, \mathrm{CDCl}_{3}, \delta\right): 198.888 \mathrm{C}=\mathrm{O}, 145.162,137.038,133.177,132.678$, $128.683,128.291,128.118,127.783,127.448,127.128,124.880,123.290,120.176,119.084,111.219,110.931$, 56.055, 45.201. ESI-MS: (m/z) M+268.0634.

(2E)-3-(3-phenoxyphenyl)-1-phenylprop-2-en-1-one (9). Yield, 88\%, (Liquid), IR (KBr: $\left.\mathrm{cm}^{1}\right) 3848(2 \mathrm{v},(\mathrm{C}=\mathrm{O})$, s-trans), $3446(2 \mathrm{v},(\mathrm{C}==\mathrm{O}), \mathrm{s}$-cis $), 3050(\mathrm{C}-\mathrm{H}$ stretch $), 1878(\mathrm{v}(\mathrm{C}=\mathrm{O})$ stretch $), 1632(\mathrm{C}=\mathrm{C}$ stretch $), 1317(\mathrm{C}=\mathrm{C}$ bending), 765 (phenyl bending). ${ }^{1} \mathrm{HNMR}\left(400 \mathrm{MHz}, \mathrm{CDCl}_{3}, \delta\right): 8.002-7.980$ (m, 1H. ArH), 7.940-7.904 (M, 1H, Ar H), 7.760-7.698 (m, 1H, ArH), 7.597-7.417 (m, 3H ArH), 7.383-7.344 (m, 2H, ArH), 7.298-7.121 (m, 3H, ArH), 7.084-7.008 (m, 2H, ArH), 6.971-6.910 (m, 1H, ArH,), 6.856-6.779 (m, 1H, ArH), 6.734-6.716 (m, $1 \mathrm{H}, \mathrm{ArH}) .{ }^{13} \mathrm{CNMR}\left(400 \mathrm{MHz} \mathrm{CDCl}_{3}, \delta\right): \delta 198.514(\mathrm{C}=\mathrm{O}), 190.534(\mathrm{C}-\mathrm{O}), 157.932,157.329,157.185,156.840$, $145.947,144.184,133.225,132.975,130.370,130.015,129.776,128.751,128.224,123.788,122.839,120.876$, 119.141, 118.806, 118.222. ESI-MS: m/z, M-H, 299.0314.

(2E)-3-(3-hydroxy-4-methoxyphenyl)-1-phenylprop-2-en-1-one (10). Yield, 79\%, mp: $110-112{ }^{\circ} \mathrm{C}$, UV-visible $(\mathrm{EtOH}) \lambda \max (\mathrm{nm}) \log (\varepsilon): 246$ (2.308), 294 (2.13860, 422 (2.4702). IR ( $\left.\mathrm{KBr} \mathrm{cm}^{1}\right): 3811(2 \mathrm{v},(\mathrm{C}=\mathrm{O}), \mathrm{s}-\mathrm{trans})$, $3662(2 \mathrm{v},(\mathrm{C}=\mathrm{O})$, s-cis), 3167 (OH stretch), 3011(C-H stretch), $1838(\mathrm{v}(\mathrm{C}=\mathrm{O})$ stretch), $1624(\mathrm{C}=\mathrm{C}$ stretch), 1391 $\left(\mathrm{C}=\mathrm{C}\right.$ bending), ${ }^{1} \mathrm{HNMR}\left(400 \mathrm{MHz}, \mathrm{CDCl}_{3}, \delta\right): 9.829(\mathrm{~s}, 1 \mathrm{H}, \mathrm{OH}$ of phenol), $7.7(\mathrm{~m}, 1 \mathrm{H}, \mathrm{ArH}), 7.583-7.369(\mathrm{~m}$, 5H, ArH), 7.276-7.249 (m, 1H, ArH), 7.140-7.114 (m, 1H, ArH), 6.873-6.829 (m, 1H, ArH) 6.769-6.711 (m, $1 \mathrm{H}, \mathrm{ArH}), 3.928\left(\mathrm{~s}, 3 \mathrm{H}-\mathrm{CH}_{3}\right){ }^{13} \mathrm{CNMR}\left(400 \mathrm{MHz} \mathrm{CDCl}_{3}, \delta\right): 198.797(\mathrm{C}=\mathrm{O}) 56.122$ (aliphatic carbon), 190.645 (C-O), 148.941, 146.004, 144.917, 138.520, 136.966, 133.161, 132.713, 128.670, 122.864, 120.347, 119.384, 113.244, 110.669. ESI-MS: (m/z) M+254.0480.

(2E)-3-(2-aminophenyl)-1-phenylprop-2-en-1-one (11). Yield, 39\%, MP: 120-122 ${ }^{\circ} \mathrm{C}$, UV-visible (EtOH) $\lambda$ max: 246 (2.2355), 296 (2.0668), 362 (1.4537) IR ( $\left.\mathrm{KBr} \mathrm{cm}^{1}\right)$ : 3856 (2v, (C=O), s-trans), 3715 (2v, (C=O), s-cis), 3403 (NH-C stretch), 1858 (C=O stretch), 1622 (C=C stretch), 1213 (C-N bending). ${ }^{1} \mathrm{HNMR}\left(400 \mathrm{MHz}, \mathrm{CDCl}_{3}, \delta\right)$ : $8.586\left(\mathrm{~S}, 2 \mathrm{H}, \mathrm{NH}_{2}\right), 8.133$ (d, 7.2 Hz, 1H, ArH), 8.006-7.788 (m, 1H, ArH), 7.681-7.440 (m, 2H, ArH), 7.3607.185 (m, 2H, ArH), 7.099-6.951 (m, 2H, ArH),6.901-6.855 (m, 1H, ArH), 6.756-6.624 (m, 2H, ArH), ${ }^{13} \mathrm{CNMR}$ $\left(400 \mathrm{MHz} \mathrm{CDCl}_{3}, \delta\right): 194.192$ (C=O), 146.042, 144.965, 140.703, 137.795, 135.821, 135.297, 133.428, 130.387, $129.042,124.809,122.578,120.166,117.448,116.409$. ESI-MS (m/z): $\mathrm{M}+\mathrm{NH}_{4}, 241.0603$.

(2E)-3-(3, 4-dihydroxyphenyl)-1-phenylprop-2-en-1-one (12). Yield: $20 \%$, mp: $186-188{ }^{\circ} \mathrm{C}$, UV-visible (EtOH) $\lambda \max (\mathrm{nm}) \log (\varepsilon): 246$ (2.2099), 288 (2.0318), 392 (2.1181), IR $\left(\mathrm{KBr} \mathrm{cm}^{1}\right): 3814(2 \mathrm{v},(\mathrm{C}=\mathrm{O}), \mathrm{s}-\operatorname{trans}), 3682(2 \mathrm{v}$, $(\mathrm{C}=\mathrm{O}) \mathrm{s}$-cis), 3478 (OH stretch), 3034 (C-H stretch), $1808 \mathrm{C}=\mathrm{O}$ stretch, $1637 \mathrm{C}=\mathrm{C}$ stretch, $1427 \mathrm{C}=\mathrm{C}$ bending, ${ }^{1} \mathrm{HNMR}\left(400 \mathrm{MHz}, \mathrm{CDCl}_{3}, \delta\right): 8.002-7.924(\mathrm{~m}, 1 \mathrm{H}, \mathrm{ArH}), 7.718-7.676(\mathrm{~m}, 1 \mathrm{H}, \mathrm{ArH}), 7.553-7.438(\mathrm{~m}, 3 \mathrm{H}$, ArH), 4.376-7.118 (m, 4H, ArH), 6.985-6.805 (m, 1H, ArH). ESI-MS (m/z): $\mathrm{M}^{+}, 240.0968$.

Molecular docking studies. Molecular docking studies were carried out to have a better understanding on the synthesized compounds interaction at the molecular level with the pathogenic microbial organisms. Two Gram-positive, two Gram-negative and two fungi strains were used in the in silico evaluation of the antimicrobial activity. The Gram-negative bacteria targets used included UDP-3-O- $((R)-3$-hydroxymyristoyl)- $N$-acetyl (PDB ID: 3P3E) for Pseudomonas aeruginosa and glutaredoxin (PDB ID: 1GRX) for E. coli. Gram-positive bacteria targets included: DNA gyrase (PDB ID: 3G75) for Staphylococcus aureus and Glucosamine-6-phosphate synthase (PDB code: 2VF5) for S.typhi The fungi targets were dihydrofolate reductase (PDB ID 1AI9) for Candida albicans, (PDB ID: 1WS3) for Aspergellus niger. The 3D structures of these drug targets with their co-crystallized ligands were obtained from the Protein Data Bank (http://www.rcsb.org) with the resolution of $2.62 \AA$. Auto- 


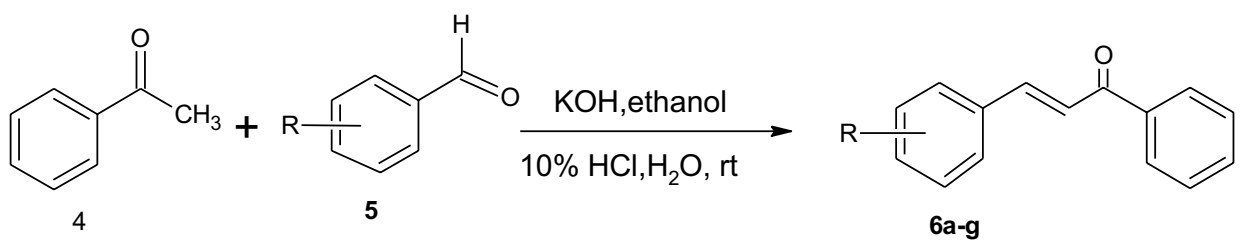

Scheme 1. Synthetic route to new chalcone derivatives.

Dock tools 1.5.4 was used to determine the grid box size for the potential binding site. The structure of the compounds was optimized with Gaussian $09^{37}$. The determined dimension was $\mathrm{X}=26, \mathrm{Y}=26, \mathrm{Z}=26$ with $1.00 \AA$ as the grid spacing. Lamarckian genetic algorithm method was applied to obtain the optimum binding site for the ligand ${ }^{38}$. Gasteiger charges were computed using Auto-Dock tools graphical user interface supplied by MGL tools $^{39}$. We however used optimal interactions and the best Auto-Dock socre for the interpretation of the best conformation.

In silico prediction. The physicochemical properties, lipophilicity, water solubility, pharmacokinetics, Druglikeness, and medicinal chemistry properties of the synthesized compounds were assessed using SwissADME online software.

\section{Biological studies}

Antimicrobial activity of the synthesized chemical compounds. Methodology. Nutrient agar and potato dextrose agar were prepared using manufacturer's guide and sterilized by autoclaving at $121^{\circ} \mathrm{C}$ for $15 \mathrm{~min}$ and stored for $42^{\circ} \mathrm{C}$ until used.

Test microorganisms used. The test microorganisms used (Staphylococcus aureus, Escherichia coli, Bacillus subtilis, Pseudomonas aeruginosa, Salmonella typhi, Candida albicans, and Aspergillus niger) were clinical isolates obtained from the Department of Pharmaceutical Microbiology and Biotechnology Laboratory, University of Nigeria, Nsukka. The test organisms were validated using 0.5 MacFaland turbid equivalents.

Preparation of the different concentration of the compounds used. A $5 \mathrm{mg} / \mathrm{mL}$ stock solution of the compounds were obtained by dissolving $10 \mathrm{mg}$ of the compounds in $2 \mathrm{~mL}$ of $50 \%$ DMSO. Different concentrations $(\mathrm{mg} / \mathrm{mL})$ of $1.0,0.9,0.8,0.7,0.6,0.5,0.4,0.3,0.2$ and 0.1 were obtained using serial dilution.

Control test (standard) The standard antibiotic used was ofloxacin, ciprofloxacin and fluconazole.

Experimental. The modified methods of $\operatorname{Cowan}^{34}$ was adopted in the antimicrobial assay. Different concentrations of the synthesized molecules were transferred into sterilized Petri dish, and $16 \mathrm{~mL}$ of sterile molten agar was added and allowed to gel. Using a permanent marker, seven equal parts were made on the plates and then the test microorganisms were added on the segments, and labeled. The culture plates were incubated for $24 \mathrm{~h}$ at $37^{\circ} \mathrm{C}$ for bacterial and $48 \mathrm{~h}$ at $25^{\circ} \mathrm{C}$ for fungi. After incubation, the plates were observed for sensitivity and further incubated for $24 \mathrm{~h}$ at $37^{\circ} \mathrm{C}$, and $48 \mathrm{~h}$ at $25^{\circ} \mathrm{C}$ to evaluate the bactericidal and fungicidal activity respectively.

Antioxidant activity. Ferrous ion chelating activity. The chelating of ferrous ions by the synthesized compounds were evaluated employing the method of Singh and Rajini ${ }^{40}$. Different concentrations of the compounds were added to $100 \mu \mathrm{L}$ of $2 \mathrm{mM}$ ferrous sulphate solution and $300 \mu \mathrm{L}$ of $5 \mathrm{mM}$ ferrozine and mixed. The mixture was incubated at room temperature for $10 \mathrm{~min}$. The absorbance of the solution was recorded at $562 \mathrm{~nm}$. Ethylene diamine tetracetate (EDTA) was used as standard. The tests were carried out in triplicate and the percentages inhibition were calculated using :

$$
\text { Percentage of inhibition }=\frac{A b s_{\text {control }}-A b s_{\text {test }}}{A b s_{\text {control }}} \times 100
$$

\section{Results and discussion}

Chemistry. Reaction of acetophenone (4) with substituted benzaldehyde (5) in basic medium, formed the chalcone derivatives (6a-g, Scheme 1) which were characterized using UV visible, FTIR, NMR, and HRMS (Scheme 2).

\section{Spectral characterization}

In the FTIR, the band at $3167 \mathrm{~cm}^{-1}$ and $3478 \mathrm{~cm}^{-1}$ in compounds $6 \mathbf{e}$ and $6 \mathrm{~g}$ respectively are due to $\mathrm{OH}$, band at $3403 \mathrm{~cm}^{-1}$ in compound $6 \mathbf{f}$ is due to $\mathrm{C}-\mathrm{NH}$ of the amine group. The bands between $1808-1878 \mathrm{~cm}^{-1}$ in all the compounds are due to $\mathrm{C}=\mathrm{O}$ stretch conjugated with olefinic bond while the bands at $1601-1637 \mathrm{~cm}^{-1}$ are due to the $\mathrm{C}=\mathrm{C}$ stretch that conjugated with a carbonyl group of ketone. The band at $821 \mathrm{~cm}^{-1}$ in compound $\mathbf{6 b}$ is due to $\mathrm{C}-\mathrm{Cl}$ stretch. These bands indicates successful formation of the desired chalcones. 


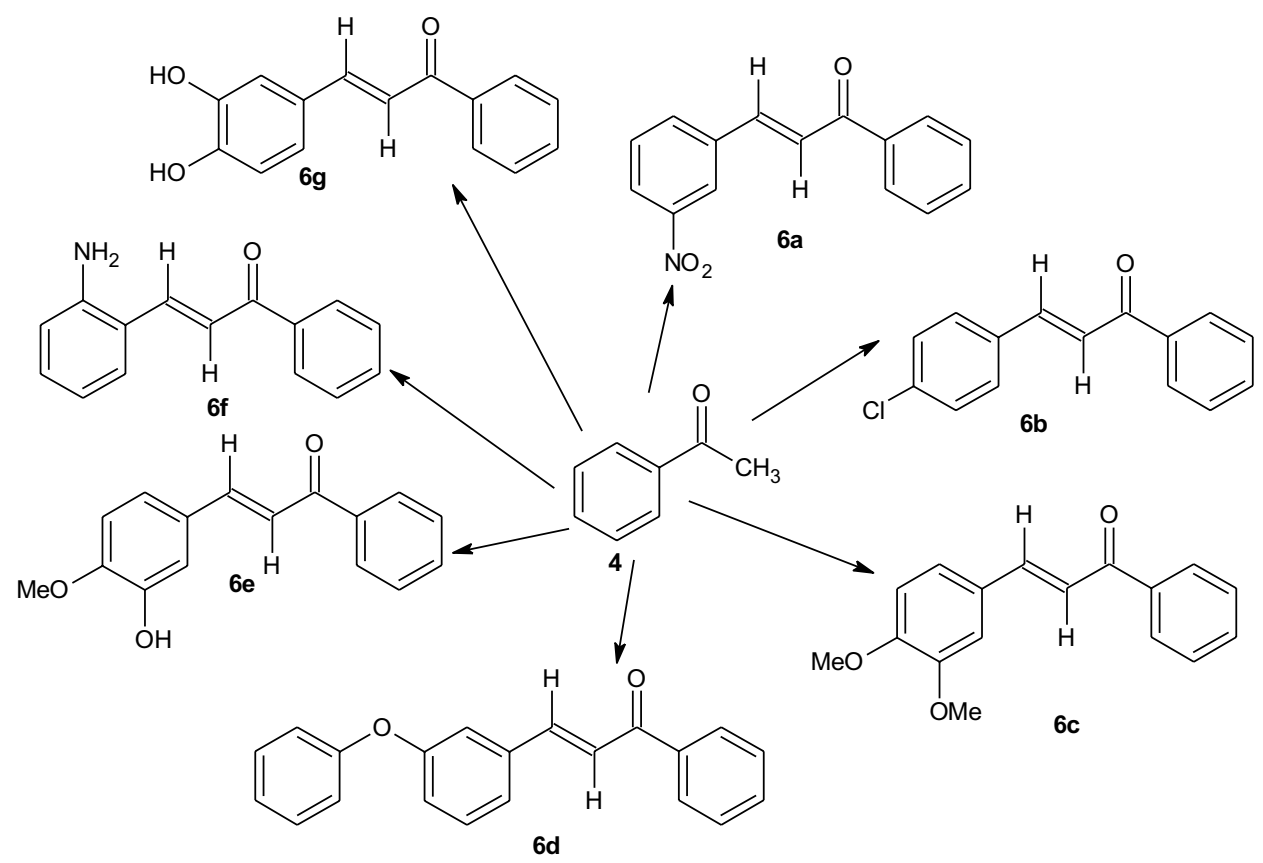

Scheme 2. Synthesis of New chalcone derivatives.

\begin{tabular}{|c|c|c|c|c|c|c|c|c|c|c|}
\hline $\mathrm{S} / \mathrm{N}$ & formula & $\begin{array}{l}\text { Molar mass (g/ } \\
\text { mol) }\end{array}$ & $\begin{array}{l}\text { Num. heavy } \\
\text { atoms }\end{array}$ & $\begin{array}{l}\text { Num. arom. } \\
\text { heavy atoms }\end{array}$ & Fraction Csp3 & $\begin{array}{l}\text { Num. rotatable } \\
\text { bonds }\end{array}$ & $\begin{array}{l}\text { Num. H-bond } \\
\text { acceptors }\end{array}$ & $\begin{array}{l}\text { Num. H-bond } \\
\text { donors }\end{array}$ & \begin{tabular}{|l|} 
Molar \\
refractivity
\end{tabular} & TPSA $(\AA)^{2}$ \\
\hline $6 a$ & $\mathrm{C}_{15} \mathrm{H}_{11} \mathrm{NO}_{3}$ & 253.25 & 19 & 12 & 0.00 & 4 & 3 & 0 & 75.07 & 62.87 \\
\hline $6 \mathbf{b}$ & $\mathrm{C}_{15} \mathrm{H}_{11} \mathrm{ClO}$ & 242.70 & 17 & 12 & 0.00 & 3 & 1 & 0 & 71.26 & 17.07 \\
\hline $6 \mathrm{c}$ & $\mathrm{C}_{17} \mathrm{H}_{16} \mathrm{O}_{3}$ & 268.31 & 20 & 12 & 0.12 & 5 & 3 & 0 & 79.23 & 35.53 \\
\hline 6d & $\mathrm{C}_{21} \mathrm{H}_{16} \mathrm{O}_{2}$ & 300.35 & 23 & 18 & 0.00 & 5 & 2 & 0 & 92.76 & 26.30 \\
\hline $6 e$ & $\mathrm{C}_{16} \mathrm{H}_{14} \mathrm{O}_{3}$ & 254.28 & 19 & 12 & 0.06 & 4 & 3 & 1 & 74.76 & 46.53 \\
\hline $6 \mathrm{f}$ & $\mathrm{C}_{15} \mathrm{H}_{13} \mathrm{NO}$ & 223.27 & 17 & 12 & 0.00 & 3 & 1 & 1 & 70.65 & 43.09 \\
\hline $6 g$ & $\mathrm{C}_{15} \mathrm{H}_{12} \mathrm{O}_{3}$ & 240.25 & 18 & 12 & 0.00 & 3 & 3 & 2 & 70.29 & 57.53 \\
\hline
\end{tabular}

Table 1. Physicochemical properties.

In the ${ }^{1} \mathrm{HNMR}$, the peak at $9.83 \mathrm{ppm}$ in compound $6 \mathbf{e}$ is assigned to the $\mathrm{OH}$ of the phenolic group. The appearance of doublet at 7.91-8.133 ppm and multiplets at 7.18-8.51 ppm were indicative of the successful formation of the desired chalcones. The appearance of singlets at 3.94 and $3.81 \mathrm{ppm}$ in compound $\mathbf{6 c}$ confirmed the presence of dimethyl group, while the appearance of singlet at $3.93 \mathrm{ppm}$ in compound $\mathbf{6 e}$ indicates the presence of a methyl group. All these indicate successful formation of the target products.

The peaks at $189-198 \mathrm{ppm}$ in the ${ }^{13} \mathrm{CNMR}$ indicates the presence of $\mathrm{C}=\mathrm{O}$ of ketone. The peaks at $190 \mathrm{ppm}$ in compounds $\mathbf{6 c}, \mathbf{6 d}$ and $\mathbf{6 e}$ are due to $\mathrm{C}-\mathrm{O}$. All the aromatic and aliphatic peaks were accounted for in the carbon-13 NMR. The carbon-13 NMR showed all the peaks expected of successful coupled products.

The high resolution mass spectrometer (HRMS) peak of the derivatives appeared as molecular ions $\left(\mathrm{M}^{+}\right)$. The results corresponded to three decimals with the calculated values. The spectra used for the characterisation of the new compounds are available as supporting documents.

Absorption, distribution, metabolism and excretion prediction. One of the procedures in drug development processes is the ability of the drug target to be orally bioP available ${ }^{41}$. Lipinski rule proposed some rules that drug target must have; the molecular weight $\leq 500$, hydrogen bond acceptor $(\mathrm{HBA}) \leq 10$, hydrogen bond donor $(\mathrm{HBD}) \leq 5$, lipophilicity $(\log \mathrm{P}) \leq 5$. The rule highlights feasible bioavailability problem if more than two tests are breached ${ }^{42}$. All the synthesized compounds obeyed the rule except compound $\mathbf{6 d}$ which has $\log \mathrm{P}$ of 5.71 as shown in Table 1.

The values of the consensus $\log P_{\mathrm{o} / \mathrm{w}}$ is an indication that the compounds are highly lipophilic and they will be distributed in the lipid regions of the body to a greater extent. The results (Table 2) indicates that the compounds will also have good absorption, distribution, metabolism and excretion characteristics since the $\log P_{\mathrm{o} / \mathrm{w}}$ is $>2$ and $<6^{43}$. 


\begin{tabular}{|c|c|c|c|c|c|c|}
\hline $\mathrm{S} / \mathrm{N}$ & $\log P_{\mathrm{o} / \mathrm{w}}$ (iLOGP) & $\log P_{\mathrm{o} / \mathrm{w}}($ XLOGP $)$ & $\log P_{\mathrm{o} / \mathrm{w}}($ WLOGP $)$ & $\log P_{\mathrm{o} / \mathrm{w}}($ MLOGP) & $\begin{array}{l}\log P_{\text {o/w }} \\
\text { (SILICOS-IT) }\end{array}$ & $\begin{array}{l}\text { Consensus } \\
\log P_{\text {o/w }}\end{array}$ \\
\hline $6 \mathbf{a}$ & 2.17 & 3.54 & 3.38 & 2.26 & 1.75 & 2.62 \\
\hline 6b & 2.82 & 3.71 & 4.13 & 3.96 & 4.57 & 3.84 \\
\hline $6 c$ & 2.99 & 4.16 & 3.49 & 2.66 & 4.01 & 3.46 \\
\hline 6d & 3.48 & 4.61 & 5.27 & 4.24 & 5.10 & 4.54 \\
\hline $6 e$ & 2.17 & 3.31 & 3.19 & 2.42 & 3.48 & 3.02 \\
\hline $6 f$ & 2.31 & 3.01 & 3.06 & 2.78 & 3.21 & 2.88 \\
\hline $6 \mathrm{~g}$ & 1.98 & 3.44 & 2.89 & 2.17 & 2.96 & 2.69 \\
\hline
\end{tabular}

Table 2. Lipophilicity.

\begin{tabular}{|c|c|c|c|c|c|c|c|c|c|}
\hline \multirow[b]{2}{*}{$\mathbf{S} / \mathbf{N}$} & \multicolumn{3}{|l|}{ ESOL } & \multicolumn{3}{|l|}{ ALI } & \multicolumn{3}{|c|}{ SILICOS-IT } \\
\hline & $\log S$ & Solubility & Class & $\log S$ & Solubility & Class & $\log S$ & Solubility & Class \\
\hline $6 a$ & -3.84 & $\begin{array}{l}3.63 \mathrm{e}-02 \mathrm{mg} / \mathrm{ml} ; \\
1.43 \mathrm{e}-04 \mathrm{~mol} / \mathrm{l}\end{array}$ & S & -4.55 & $\begin{array}{l}7.21 \mathrm{e}-03 \mathrm{mg} / \mathrm{ml} \\
2.85 \mathrm{e}-05 \mathrm{~mol} / \mathrm{l}\end{array}$ & MS & -4.34 & $\begin{array}{l}1.16 \mathrm{e}-02 \mathrm{mg} / \mathrm{ml} ; \\
4.59 \mathrm{e}-05 \mathrm{~mol} / \mathrm{l}\end{array}$ & MS \\
\hline $6 b$ & -4.01 & \begin{tabular}{|l|}
$2.39 \mathrm{e}-02 \mathrm{mg} / \mathrm{ml}$ \\
$9.85 \mathrm{e}-05 \mathrm{~mol} / \mathrm{l}$ \\
\end{tabular} & MS & -3.76 & $\begin{array}{l}4.22 \mathrm{e}-02 \mathrm{mg} / \mathrm{ml} ; \\
1.74 \mathrm{e}-04 \mathrm{~mol} / \mathrm{l} \\
\end{array}$ & $\mathrm{S}$ & -5.58 & \begin{tabular}{|l|}
$6.46 \mathrm{e}-04 \mathrm{mg} / \mathrm{ml} ;$ \\
$2.66 \mathrm{e}-06 \mathrm{~mol} / \mathrm{l}$ \\
\end{tabular} & MS \\
\hline $6 c$ & -4.24 & $\begin{array}{l}1.55 \mathrm{e}-02 \mathrm{mg} / \mathrm{ml} \\
5.78 \mathrm{e}-05 \mathrm{~mol} / \mathrm{l}\end{array}$ & MS & -4.61 & $\begin{array}{l}6.52 \mathrm{e}-03 \mathrm{mg} / \mathrm{ml} \\
2.43 \mathrm{e}-05 \mathrm{~mol} / \mathrm{l}\end{array}$ & MS & -5.21 & $\begin{array}{l}1.66 \mathrm{e}-03 \mathrm{mg} / \mathrm{ml} ; \\
6.18 \mathrm{e}-06 \mathrm{~mol} / \mathrm{l}\end{array}$ & MS \\
\hline $6 d$ & -4.86 & $\begin{array}{l}4.19 \mathrm{e}-03 \mathrm{mg} / \mathrm{ml} ; \\
1.39 \mathrm{e}-05 \mathrm{~mol} / \mathrm{l}\end{array}$ & MS & -4.89 & $\begin{array}{l}3.89 \mathrm{e}-03 \mathrm{mg} / \mathrm{ml} ; \\
1.30 \mathrm{e}-05 \mathrm{~mol} / \mathrm{l}\end{array}$ & MS & -7.20 & $\begin{array}{l}1.90 \mathrm{e}-05 \mathrm{mg} / \mathrm{ml} ; \\
6.32 \mathrm{e}-08 \mathrm{~mol} / \mathrm{l}\end{array}$ & PS \\
\hline $6 e$ & -3.71 & $\begin{array}{l}5.01 \mathrm{e}-02 \mathrm{mg} / \mathrm{ml} ; \\
1.97 \mathrm{e}-04 \mathrm{~mol} / \mathrm{l}\end{array}$ & $S$ & -3.96 & $\begin{array}{l}2.77 \mathrm{e}-02 \mathrm{mg} / \mathrm{ml} \\
1.09 \mathrm{e}-04 \mathrm{~mol} / \mathrm{l}\end{array}$ & $\mathrm{s}$ & -4.51 & $\begin{array}{l}7.86 \mathrm{e}-03 \mathrm{mg} / \mathrm{ml} ; \\
3.09 \mathrm{e}-05 \mathrm{~mol} / \mathrm{l}\end{array}$ & MS \\
\hline $6 f$ & -3.44 & $\begin{array}{l}8.02 \mathrm{e}-02 \mathrm{mg} / \mathrm{ml} ; \\
3.59 \mathrm{e}-04 \mathrm{~mol} / \mathrm{l}\end{array}$ & S & -3.58 & $\begin{array}{l}5.88 \mathrm{e}-02 \mathrm{mg} / \mathrm{ml} \\
2.63 \mathrm{e}-04 \mathrm{~mol} / \mathrm{l}\end{array}$ & $S$ & -4.6 & $\begin{array}{l}5.60 \mathrm{e}-03 \mathrm{mg} / \mathrm{ml} ; \\
2.51 \mathrm{e}-05 \mathrm{~mol} / \mathrm{l}\end{array}$ & MS \\
\hline $6 \mathrm{~g}$ & -3.79 & $\begin{array}{l}3.88 \mathrm{e}-02 \mathrm{mg} / \mathrm{ml} ; \\
1.61 \mathrm{e}-04 \mathrm{~mol} / \mathrm{l}\end{array}$ & S & -4.33 & $\begin{array}{l}1.13 \mathrm{e}-02 \mathrm{mg} / \mathrm{ml} \\
4.69 \mathrm{e}-05 \mathrm{~mol} / \mathrm{l}\end{array}$ & MS & -3.81 & $\begin{array}{l}3.72 \mathrm{e}-02 \mathrm{mg} / \mathrm{ml} ; \\
1.55 \mathrm{e}-04 \mathrm{~mol} / \mathrm{l}\end{array}$ & S \\
\hline
\end{tabular}

Table 3. Water solubility. $S$ soluble, $M S$ moderately soluble, $P S$ poorly soluble.

\begin{tabular}{|l|l|l|l|l|l|l|l|l|l|}
\hline S/N & GI absorption & BBB permeant & P-gp substrate & $\begin{array}{l}\text { CYP1A2 } \\
\text { inhibitor }\end{array}$ & $\begin{array}{l}\text { CYP2C19 } \\
\text { inhibitor }\end{array}$ & $\begin{array}{l}\text { CYP2C9 } \\
\text { inhibitor }\end{array}$ & $\begin{array}{l}\text { CYP2D6 } \\
\text { inhibitor }\end{array}$ & $\begin{array}{l}\text { CYP3A4 } \\
\text { inhibitor }\end{array}$ & Log K (cm/s) \\
\hline 6a & High & Yes & No & Yes & Yes & Yes & No & No \\
\hline 6b & High & Yes & No & Yes & Yes & Yes & No & No \\
\hline 6c & High & Yes & No & Yes & Yes & Yes & Yes & No & -5.15 \\
\hline 6d & High & Yes & No & Yes & Yes & Yes & No & Yes & -4.98 \\
\hline 6e & High & Yes & No & Yes & Yes & Yes & No & -4.86 \\
\hline 6f & High & Yes & No & Yes & Yes & Yes & No & No & -5.50 \\
\hline 6g & High & Yes & No & Yes & No & Yes & No & Yes & -5.52 \\
\hline
\end{tabular}

Table 4. Pharmacokinetics.

The water solubility of the compounds (Table 3) as predicted by SwissADME software shows that compound $\mathbf{6 e}, \mathbf{6 f}$ and $\mathbf{6 g}$ will have more absorption and distribution in the aqueous region of the body than compound $\mathbf{6 a}$, $\mathbf{6 b}$ and $\mathbf{6 c}$ while compound $\mathbf{6 d}$ will have poor absorption and distribution in the aqueous region of the body.

The results of pharmacokinetics prediction is presented in Table 4. The high GI adsorption is an indication that the compounds will be broken down and digested very quickly in the body and it will be largely absorbed by the small intestine. The BBB (blood brain barrier) regulates an external surface interaction between the blood and the brain, the $\mathrm{BBB}$ result above, it shows that the compounds can have access to the central nervous system (CNS), so it can be used to treat any infection of the central nervous system. The negative value of $\log \mathrm{K}_{\mathrm{p}}$ shows that it is likely to have a low skin permeability.

Permeability glycoprotein (P-gp) major role is to protect the central nervous system from xenobioties. The synthesized compound is not a good P-gp substrate and so it is not a good inhibitor of xenobiotics. The drug is an inhibitor of CPY450 enzymes, so it blocks the metabolic activities of one or more CYP450 enzymes.

The compounds obeyed Lipinski, Ghose, Veber, Egan and muegge rule of five (Table 5) therefore, they will be orally bioactive in systematic circulation and the bioavailability score of 0.55 shows that the compounds can act as good oral drugs.

The pan-assay interference compounds (PAINS) and Brenk alert allows the identification of potentially problematic fragments in the studied molecules, from the Table 6, the compounds are said to contain problematic 


\begin{tabular}{|l|l|l|l|l|l|l|}
\hline S/N & Lipinski & Ghose & Veber & Egan & Muegge & Bioavailability score \\
\hline 6a & Yes & Yes & Yes & Yes & Yes & 0.55 \\
\hline 6b & Yes & Yes & Yes & Yes & No & 0.55 \\
\hline 6c & Yes & Yes & Yes & Yes & Yes & 0.55 \\
\hline 6d & Yes & Yes & Yes & Yes & Yes & 0.55 \\
\hline 6e & Yes & Yes & Yes & Yes & Yes & 0.55 \\
\hline 6f & Yes & Yes & Yes & Yes & Yes & 0.55 \\
\hline 6g & Yes & Yes & Yes & Yes & Yes & 0.55 \\
\hline
\end{tabular}

Table 5. Druglikeness.

\begin{tabular}{|l|l|l|l|l|}
\hline S/N & PAINS & Brenk & Leadlikeness & Synthetic accessibility \\
\hline $6 \mathrm{a}$ & 0 alert & 3 alert & No & 2.65 \\
\hline $6 \mathrm{~b}$ & 0 alert & 1 alert & No & 2.42 \\
\hline 6c & 0 alert & 1 alert & No & 2.61 \\
\hline 6d & 0 alert & 1 alert & No & 2.84 \\
\hline 6e & 0 alert & 1 alert & Yes & 2.48 \\
\hline 6f & 0 alert & 2 alert & No & 2.53 \\
\hline 6g & 1 alert & 2 alert & No & 2.42 \\
\hline
\end{tabular}

Table 6. Medicinal chemistry.

\begin{tabular}{|c|c|c|c|c|c|c|}
\hline & \multicolumn{2}{|c|}{ Gram-positive bacteria } & \multicolumn{2}{|c|}{ Gram-negative bacteria } & \multicolumn{2}{|l|}{ Fungi } \\
\hline & B. subtilis (2V F5) & S.aureus (3G75) & $\begin{array}{l}\text { P.aeruginosa } \\
\text { (3P3E) }\end{array}$ & E.coli (1GRX) & C.albicans (1AI9) & A.niger (1WS3) \\
\hline \multicolumn{7}{|l|}{ Compound } \\
\hline $6 \mathrm{a}$ & -10.29 & -10.86 & -10.49 & -9.20 & -10.91 & -9.46 \\
\hline 6b & -9.32 & -9.40 & -9.49 & -8.07 & -10.17 & -9.44 \\
\hline $6 c$ & -10.69 & -10.55 & -11.45 & -8.99 & -11.70 & -9.58 \\
\hline 6d & -9.20 & -10.81 & -10.48 & -8.79 & -11.68 & -9.60 \\
\hline $6 e$ & -11.54 & -11.32 & -13.09 & -10.15 & -11.47 & -10.95 \\
\hline $6 f$ & -8.97 & -9.81 & -9.61 & -8.46 & -11.00 & -9.07 \\
\hline $6 \mathrm{~g}$ & -12.53 & -11.99 & -12.54 & -10.85 & -12.39 & -10.77 \\
\hline Std drug & -12.93 & -12.12 & -13.22 & -11.20 & -10.70 & -9.40 \\
\hline Native ligand & -13.61 & -10.29 & -11.68 & -12.81 & -19.04 & -7.03 \\
\hline
\end{tabular}

Table 7. Binding free energy $(\Delta \mathrm{G})$ of the compounds. Standard drugs: ciproflocin and fluconazole.

fragments. Compound $\mathbf{6 e}$ has leadlikeness which implies that the compound can be subjected to chemical modifications while compounds $\mathbf{6 a}, \mathbf{6 b}, \mathbf{6 c}, \mathbf{6 d}, \mathbf{6 f}$ and $\mathbf{6 g}$ has no leadlikeness therefore, they cannot be subjected to chemical modifications ${ }^{44}$. The synthetic accessibility score for the compounds are far less than 5 therefore, the compounds can easily be synthesized.

Looking at their binding affinities compared with ciprofloxacin and fluconazole as the standards, the compound all had good binding affinity with the target microorganism proteins but, compounds $6 \mathbf{e}$ and $\mathbf{6 g}$ showed better binding affinity when compared with the standard as shown in Table 7 . The docking protocol was validated using $3 \mathrm{P} 3 \mathrm{E}$ as shown in Fig. 1.

Closer studies on compounds $\mathbf{6 e}$ and $\mathbf{6 g}$ were carried out with the receptor 2VF5 and 1WS3 as shown in Figs. 2, 3, 4, 5 and 6 to gain more insight about the compound interaction with the proteins of the microorganisms. Figure 2 showed the binding interaction between compound $6 \mathbf{e}$ with the amino acid 3P3E of the receptor respectively. Hydrogen bond; ARG:201, Van der waals; MET: 62, THR: 190, PHE:191, GLY:192, ILE:215, VAL:211, amide-Pi stack; GLY:209, SER:210 while Pi-alkyl; ALA: 206, LEU:18, ALA:214 and ILE:197. These representations showed that there are significant hydrogen bond interaction between the amino residues 2VF5 of the organisms and the compound as indicated on the Fig. 6 and Table 8. Figure 3 showed the binding pose of compound $\mathbf{6 g}$ in the cavity of 2VF5, an indication of outstanding hydrogen bonding interaction between the compound and the amino residues making the compound to have high binding affinity with the organisms. Table 9 also showed the interaction between the amino residue and the compound $\mathbf{6 g}$; the proteins involved the types of hydrogen 


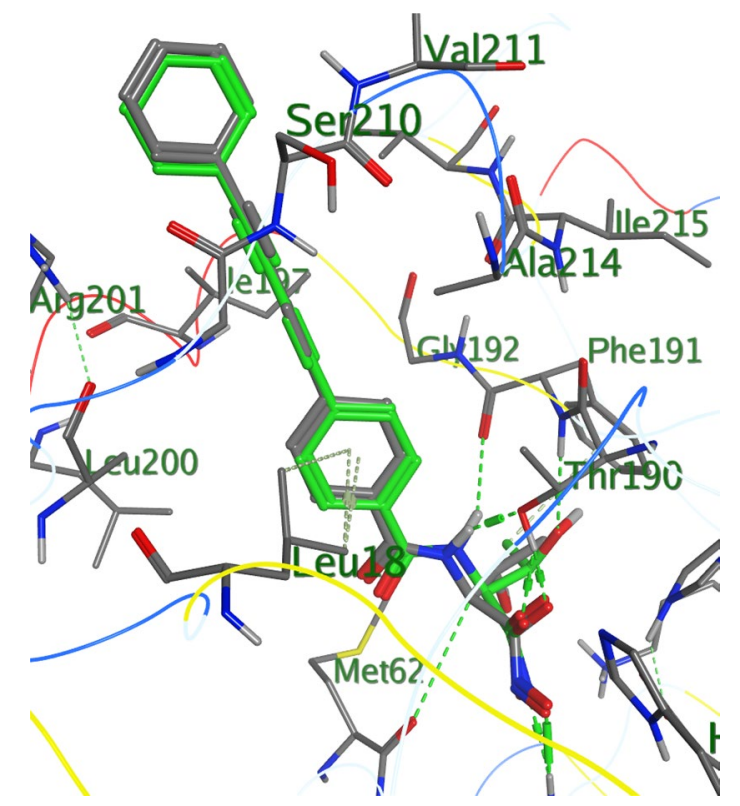

Figure 1. Validation of docking protocol using 3P3E (retrieved co-crystallized ligand (green) is docked into the binding cavity of 3P3E and is superimposed on the co-cystallized ligand (grey) intact with 3P3E.

\section{A:LEU:200}

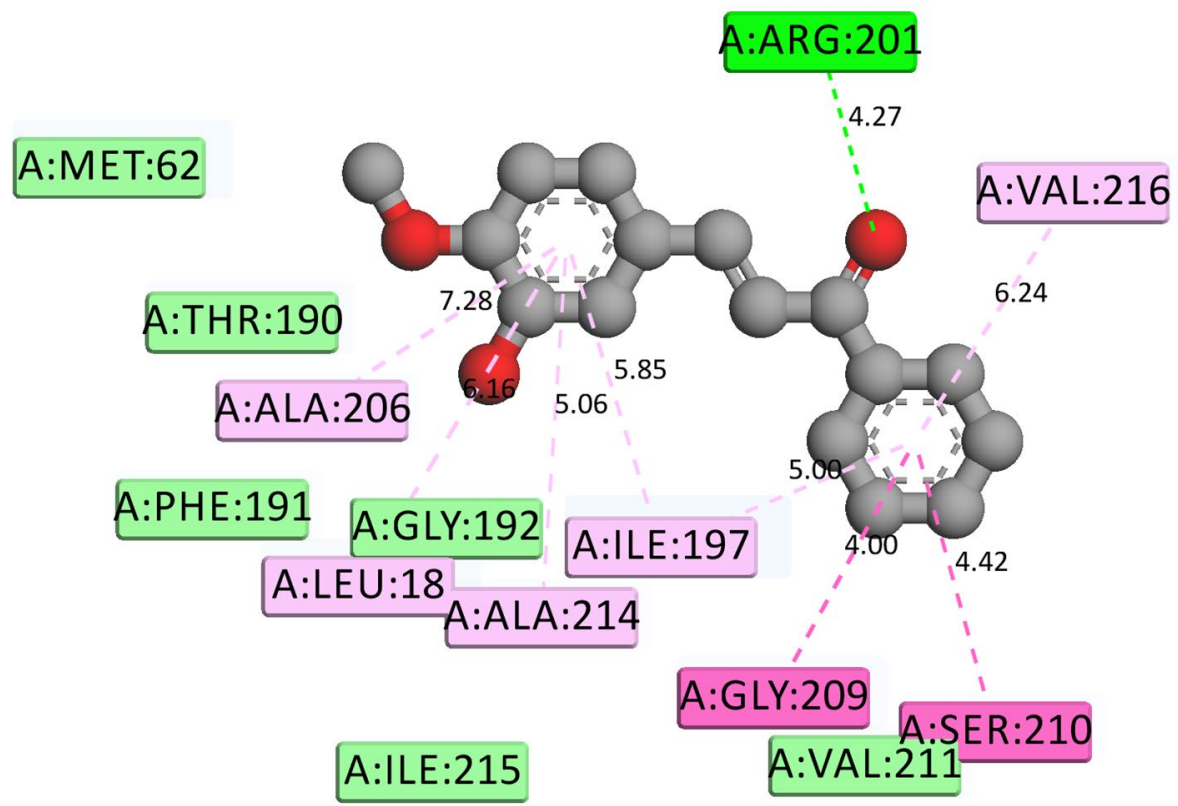

\section{Interactions}

van der Waals

Conventional Hydrogen Bond

Carbon Hydrogen Bond

\section{Amide-Pi Stacked}

Pi-Alkyl

Figure 2. Rrepresentation of the binding interactions between compound $6 \mathbf{e}$ and the amino residues of 3P3E. 


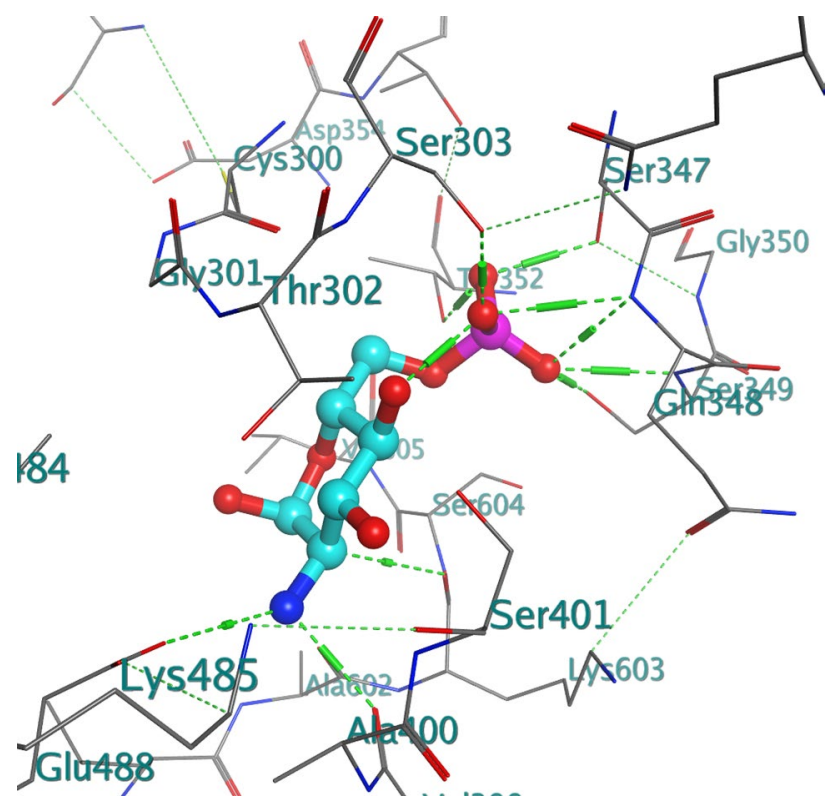

Figure 3. Binding pose of compound $6 \mathbf{g}$ in the binding cavity of 2 VF5.

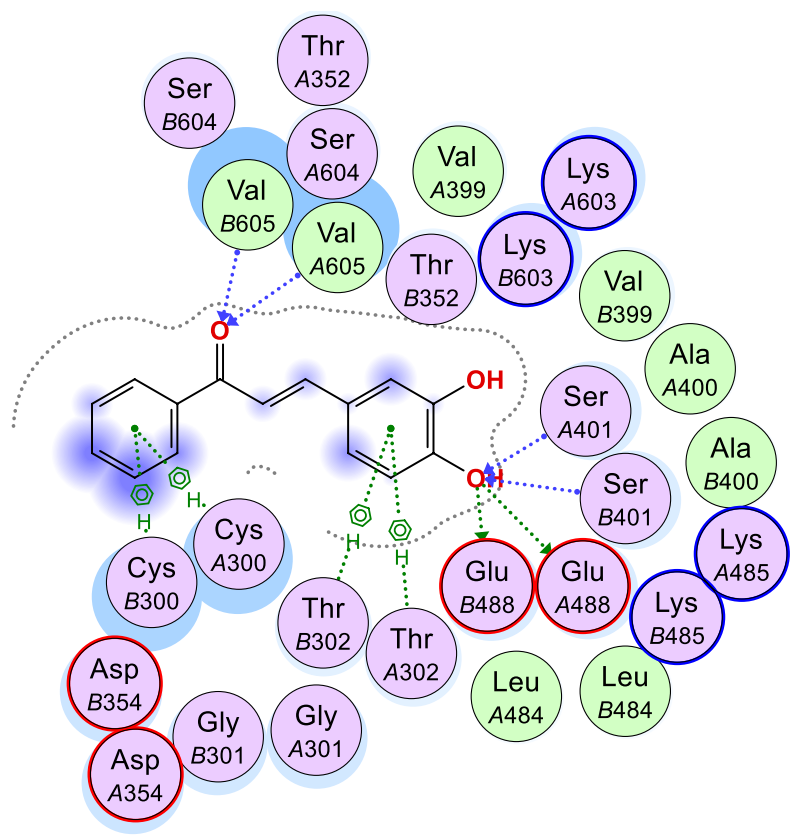

Figure 4. 2D representation of the binding interactions between compound $\mathbf{6 g}$ and the amino residues of 2VF5.

interactions, bond lengths and bonding energies. Because of these interactions, compounds $6 \mathbf{e}$ and $\mathbf{6 g}$ can be said to have drug target since they show good antagonist on the biochemical processes of the receptors. We observed that the standard drugs and co-crystalized ligands had better antibacterial activity than the reported derivatives, however, the synthesized derivatives showed better antifungal activity in the in silico experiment.

In vitro antimicrobial activities. The results of the antimicrobial assays (Tables 10 and 11), revealed that all the compounds were active against Staphylococcus aureus and Bacillus subtilis with minimium inhibitory concentrations (MIC) between $0.4-0.6 \mathrm{mg} / \mathrm{mL}$. Compounds $\mathbf{6 a}, \mathbf{6 c}$ and $\mathbf{6 d}$ have moderate activities on Salmonella typhi. Compounds $\mathbf{6 b}$ and $\mathbf{6 c}$ have moderate activity on Escherichia coli. Compound 109 has moderate activity on Aspergillus niger, compounds 6a and $\mathbf{6 e}$ had poor activities on Escherichia coli and Aspergillus niger while compound $\mathbf{6 c}$ had moderate inhibitory activity on Aspergillus niger, compound $\mathbf{6 e}$ had moderate inhibition 


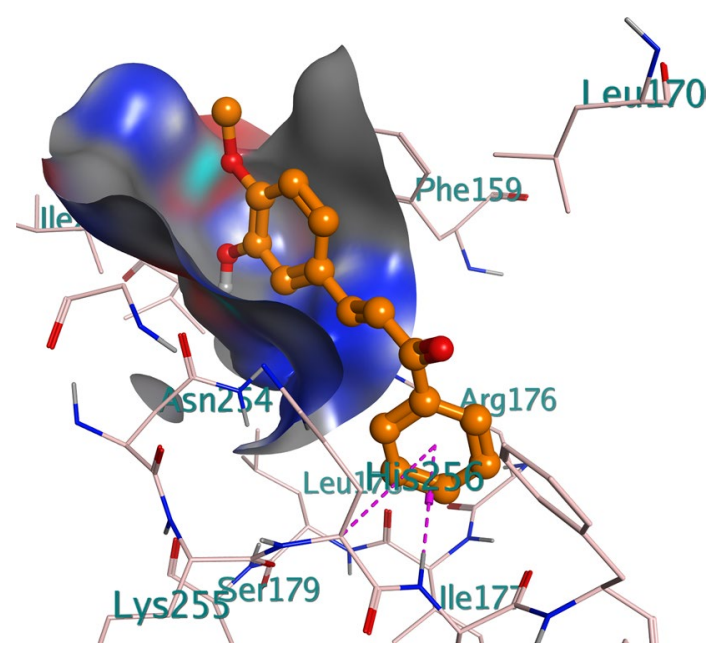

Figure 5. Binding pose of compound 6e in the binding cavity of 1WS3.

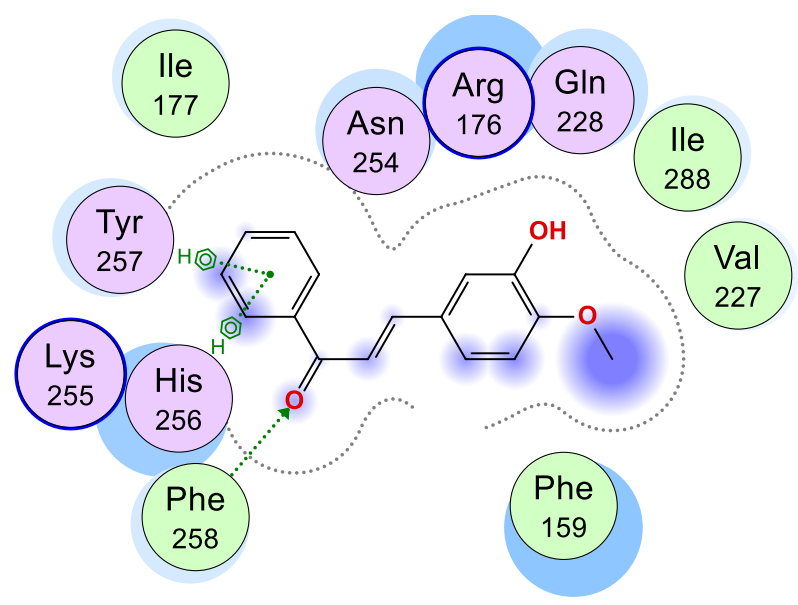

Figure 6. $2 \mathrm{D}$ representation of the binding interactions between compound $6 \mathrm{e}$ and the amino residues of $2 \mathrm{VF} 5$.

\begin{tabular}{|l|l|l|l|l|}
\hline Ligand & Receptor & Interaction & Distance $(\AA)$ & E (kcal/mol) \\
\hline O 1 & OE2 GLU 488 & H-donor & 2.96 & -0.7 \\
\hline O 1 & OE2 GLU 488 & H-donor & 2.96 & -0.7 \\
\hline O 1 & N SER 401 & H-acceptor & 2.98 & -0.3 \\
\hline O 1 & N SER 401 & H-acceptor & 2.98 & -0.3 \\
\hline O 12 & N VAL 605 & H-acceptor & 3.36 & -0.5 \\
\hline O 12 & N VAL 605 & H-acceptor & 3.36 & -0.5 \\
\hline 6-ring & CB CYS 300 & pi-H & 4.16 & -0.2 \\
\hline 6-ring & N THR 302 & pi-H & 4.46 & -0.3 \\
\hline 6-ring & CB CYS 300 & pi-H & 4.16 & -0.2 \\
\hline 6-ring & N THR 302 & pi-H & 4.46 & -0.3 \\
\hline
\end{tabular}

Table 8. Chemical interactions of compound $6 \mathrm{~g}$ with amino residues of 2 VF5.

on Pseudomonas aeruginosa. All the compounds except compound 6e had no inhibition activity against Pseudomonas aeruginosa. Only compound $\mathbf{6 d}$ had activity on Pseudomonas aeruginosa. All the compounds screened had poor activity on Aspergillus niger except compound $\mathbf{6 c}$ that showed moderate activity. None of the reported compounds had antimicrobial activity comparable with the standard drugs. We therefore would consider further optimization of the active derivatives. We also noticed that in spite of the good in silico results against C. albicans protein, the compounds were inactive against $\mathrm{C}$. albicans suggesting that the concentration used for the assay 


\begin{tabular}{|l|l|l|l|l|}
\hline Ligand & Receptor & Interaction & Distance $(\AA)$ & $\mathbf{E}(\mathbf{k c a l} / \mathbf{m o l})$ \\
\hline O 13 & CE1 PHE 258 & H-acceptor & 3.82 & -0.2 \\
\hline 6-ring & CA HIS 256 & pi-H & 4.26 & -0.5 \\
\hline 6-ring & N TYR 257 & pi-H & 4.06 & -1.3 \\
\hline
\end{tabular}

Table 9. Chemical interactions of compound 6e with amino residues of 2VF5.

\begin{tabular}{|l|l|l|l|l|l|l|l|}
\hline Compound & E. coli & S. typhi & S. aureus & B. subtilis & P. aeruginosa & C. albicans & A. niger \\
\hline 6a & 0.9 & 0.7 & 0.4 & 0.6 & NA & NA & 0.9 \\
\hline 6b & 0.6 & 0.8 & 0.6 & 0.5 & NA & NA & 0.9 \\
\hline 6c & 0.7 & 0.7 & 0.4 & 0.4 & NA & NA & 0.9 \\
\hline 6d & NA & 0.6 & 0.4 & 0.5 & NA & 0.8 & 0.9 \\
\hline $\mathbf{6 e}$ & 0.9 & 0.8 & 0.5 & 0.4 & 0.8 & NA & 0.9 \\
\hline 6f & & & & & & & \\
\hline 6g & & & & & & & \\
\hline Ciprofloxacin & 0.02 & 0.015 & 0.025 & 0.020 & 0.025 & NA & NA \\
\hline Fluconazole & NA & NA & NA & NA & NA & 0.020 & 0.005 \\
\hline
\end{tabular}

Table 10. Minimum inhibitory concentration (MIC, mg/mL). NA no activity.

\begin{tabular}{|l|l|l|l|l|l|}
\hline \multirow{2}{*}{ \% of inhibition } & \multicolumn{4}{|l|}{} & \multirow{2}{*}{} \\
\cline { 2 - 5 } Compound & $\mathbf{1 2 5}$ & $\mathbf{2 5 0}$ & $\mathbf{5 0 0}$ & $\mathbf{1 0 0 0}$ & IC $\mathbf{5 0}(\boldsymbol{\mu g} / \mathbf{m l})$ \\
\hline $\mathbf{6 a}$ & NI & 43.75 & 85.94 & 94.79 & 246.5 \\
\hline $\mathbf{6 b}$ & NI & NI & NI & NI & 0.0 \\
\hline $\mathbf{6 c}$ & 81.77 & 89.58 & 86.46 & 93.75 & 1.71 \\
\hline $\mathbf{6 d}$ & NI & NI & 70.31 & 70.31 & 353.15 \\
\hline 6e & 70.31 & 73.43 & 73.44 & 75.52 & 6.30 \\
\hline 6f & 67.71 & 75.52 & 67.71 & 80.73 & 2.33 \\
\hline EDTA & 54.17 & 54.17 & 55.21 & 71.35 & 3.04 \\
\hline
\end{tabular}

Table 11. Ferrous ion chelating activity. NI no inhibition.

is below the active concentration. However, the in silico results is in agreement with the results obtained from the invitro experiment which strongly suggest the inhibition of the tested enzymes in the in vitro experiments.

Antioxidant activity. The compounds were assessed for their in-vitro antioxidant activities using ethylenediamine tetracetate (EDTA) as the standard. Compounds $\mathbf{6 c}, \mathbf{6 e}$ and $\mathbf{6 g}$ gave excellent inhibitory activities above those of the standard. Compound $\mathbf{6 a}$ gave good activity at $500 \mu \mathrm{g} / \mathrm{mL}$ and $100 \mu \mathrm{g} / \mathrm{mL}$ concentrations but, below the standard at $250 \mu \mathrm{g} / \mathrm{ml}$ and no inhibition at $125 \mu \mathrm{g} / \mathrm{mL}$. Compound $\mathbf{6 d}$ had good inhibition at $500 \mu \mathrm{g} /$ $\mathrm{mL}$ and $1000 \mu \mathrm{g} / \mathrm{mL}$ but, no inhibition at $125 \mu \mathrm{g} / \mathrm{mL}$ and $250 \mu \mathrm{g} / \mathrm{mL}$. Compound $\mathbf{6 b}$ was found to be inactive in all the concentrations. The IC50 values showed that only compounds $\mathbf{6 c}$ and $\mathbf{6} \mathbf{f}$ had better antioxidant activity.

\section{Conclusions}

In this paper, we have described a versatile approach to obtain chalcone derivatives. All the compounds were evaluated for their antimicrobial and antioxidant activities. Compound $\mathbf{6 b}$ was the most active against E. Coli, compound $\mathbf{6 d}$ was the most potent against $S$. typhi, compounds $\mathbf{6 a}, \mathbf{6 c}$ and $\mathbf{6 d}$ had the same activity (MIC $0.4 \mathrm{mg} /$ $\mathrm{mL}$ ) againt $S$. aureus, compounds $\mathbf{6 c}$ and $\mathbf{6 e}$ were the most active (MIC $0.4 \mathrm{mg} / \mathrm{mL}$ ) against B. subtilis only compound $\mathbf{6 d}$ showed activity (MIC $0.8 \mathrm{mg} / \mathrm{mL}$ ) against C. albicans, only compound $\mathbf{6 e}$ showed activity (MIC $0.8 \mathrm{mg} / \mathrm{mL}$ ) against $P$. aeruginosa while all the compounds were active against $A$. niger. Compound $\mathbf{6 c}$ had highest antioxidant activity. SwissADME was used to predict the absorption, distribution, metabolism and excretion properties of the compounds and the results showed that the reported derivatives have druggable properties. In particular, compound 6e was reported to be drug-like.

Received: 6 April 2021; Accepted: 14 October 2021

Published online: 05 November 2021 


\section{References}

1. Christopher, W. Molecular mechanisms that confer antibacterial drug resistance. Nature 406, 775 (2000).

2. Eze, F. U., Okoro, U. C., Ugwu, D. I. \& Okafor, S. N. Biological activity evaluation of some new benzenesulphonamide derivatives. Front. Chem. 7, 634. https://doi.org/10.3389/fchem.2019.00634 (2019).

3. Hazra, B., Santana, B. \& Nripendranath, M. Antioxidant and free radicals scavenging activity of spondias pinnata. J. BMC 8, 63 (2008).

4. Polterat, O. Antioxidants and free radical scavengers of natural origin. Curr. Org. Chem 1, 415-440 (1997).

5. Chandra, A., Somali, S. \& Orrenius, S. Triggering and modulation of apoptosis by oxidative stress free radical. Biol. Med. 29, 323-333 (2000).

6. Niki, E., Shimaski, H., Mino, M. Antioxidant free radical and biological defence. Gakkai Syuppon Centre Tokyo. 3-16 (1994).

7. Robak, J. \& Marcinkiewicz, E. Scavenging of reactive oxygen species as the mechanism of drug action. Pol. J. Pharmacol. Pharm. 47, 89-98 (1995)

8. Madhavi, D. L. \& Salunkhe, D. K. Toxicological Aspects of Food Antioxidants. Food Antioxidants 267 (Dekker, New York, 1995).

9. Ugwu, D. I. et al. Synthesis and antimalarial activities of chalcone derivatives. Int. J. ChemTech Res. 7(4), 1966-1984 (2015).

10. De Vincenzo, R., Seambla, G., Panici, P. \& Remelletti, F. O. Anticancer Drugs Des. 10(6), 481-490 (1995).

11. Kaw, H. H., Wang, L. T. H. \& Wang, J. P. Chem. Abstr. 128, 22568n (1998).

12. Jung, S. H. et al. Chem. Pharm. Bull 54, 368 (2006).

13. Ahmed, M. R., Sastry, V. G., Bano, N., Ravichandra, S. \& Rasayan, M. R. J. Chem 4(2), 289-294 (2011)

14. Rongshi, L., Xiaowa, C., Baougng, G. \& Dominguez, J. N. J. Med. Chem 38(26), 5031-5037 (1995).

15. Tomcufak, A.S., Wilkson, R.G. and Child, R.G. (1975). German Patent 2502490.

16. Bhatt, A. R., Bhamaria, R. P., Patel, M. R., Bellare, R. A. \& Deliwala, C. V. Indian Chem. 10(7), 694 (1972).

17. Binder, D., Noe, C. R., Holzer, W. \& Rosenwirth, B. Arch. Pharm. 318(1), 48 (1985).

18. Gaurav, V. M. \& Ingle, D. B. Indian J. Chem. 25B(8), 868 (1986).

19. Vanstone, A. E., Maile, G. K. \& Nalbantoglu, L. K. Ger. Offen. De 3(537), 207 (1986).

20. Prescott, B. Int. J. Clin. Pharmacol. Bio. Pharm. 11(4), 332 (1975).

21. Bowden, K., Dal, P. A. \& Shah, C. K. J. Chem. Res. Synop 12, 2801 (1990).

22. Marmo, E., Caputi, A. P. \& Cataldi, S. Farmaco Ed. Prat. 28(3), 132 (1973).

23. Krbeckek,. J. Agr. Food Chem 16, 108 (1968).

24. Sundar, K. S. Proc. Indian Acad. Sci 67, 259 (1964).

25. Sundar, K. S. Proc. Indian Acad. Sci 67, 90 (1968).

26. Misra, S. S. \& Nath, B. Indian. J. Appl. Chem 34, 260 (1971).

27. Misra, S. S. J. Indian Chem Soc 50, 355 (1973).

28. Aries, R. Ger. Pat 2, 341514 (1974).

29. Prasad, Y. R., Rao, A. L., Rambabu, R. \& Ravikumar, P. J. Chem. 23, 927-937 (2007).

30. Ugwu, D. I. et al. Synthesis and pharmacological applications of chalcones: A review. Int. J. Chem. Sci. 13(1), 459-500 (2015).

31. Circu, M. L. \& Aw, T. Y. Reactive oxygen species, cellular redox systems, and apoptosis. Free Radic. Biol. Med. 48(6), 749-762 (2010).

32. Forman, H. J., Maiorino, M. \& Ursini, F. Signaling functions of reactive oxygen species. Biochemistry 49(5), 835-842 (2010).

33. Araújo, M. G. F. et al. Correlation among Antioxidant, Antimicrobial, Hemolytic, and Antiproliferative Properties of Leiothrix spiralis Leaves Extract. Int. J. Mol. Sci. 13, 9260-9277 (2012).

34. Cowan, N. M. Plant products as antimicrobial agents. Clin. Microbiol. Rev. 12, 564-582 (1999).

35. Bartling, C. M. \& Raetz, C. R. Steady-state kinetics and mechanism of LpxD, the N-acyltransferase of lipid A biosynthesis. Biochemistry 47(19), 5290-5302 (2008).

36. Evans-Roberts, K. et al. DNA Gyrase is the target for the quinolone drug ciprofloxacin in Arabidopsis thaliana. J. Biol. Chem. 291(7), 3136-3144 (2016).

37. Frisch, M.J., Trucks, G.W., Schlegel, H.B., Scuseria, G.E., Robb, M.A., Cheeseman, J.R. Scalmani, G., Barone, V., Peterson, G.A., Nakatsuji, H., Li, X., Wallingford. C.T. Gaussian Inc. 2009

38. Yang, B., Hao, Y., Li, J., Chen, D. \& Liu, R. J. Photochem. Photobiol. B 128, 35-42 (2013).

39. Morris, G. M. et al. J. Comput. Chem. 30(16), 2785-2791 (2009).

40. Sadula, A., Peddaboina, U. R. \& Prameela, S. N. J. Synthesis and characterization of novel chalcone linked imidazolones as potential antimicrobial and antioxidant agents. Med. Chem. Res. 24(2), 851-859 (2015).

41. Ibezim, K., Onyia, F. \& Ntie-Kang, and Nwodo, N. J... Drug-like properties of potential anti-cancer compounds from Cameroonian flora: A virtual study. J. Appl. Pharm. Sci. 5(6), 133-137 (2015).

42. Lipinski, C. A., Lombardo, F., Dominy, B. W. \& Feeney, P. J. Experimental and computational approaches to estimate solubility and permeability in drug discovery and development settings. Adv. Drug Deliv. Rev. 46(1-3), 3-26 (2001).

43. Muegge, I., Heald, S. L. \& Brittelli, D. Selection criteria for drug-like chemical matter. J. Med. Chem. 44, 1841-1846.TTv (2001).

44. Hann, M. M. \& Keserü, G. M. Finding the sweet spot: the role of nature and nurture in medicinal chemistry. Nat. Rev. Drug Discov. 11, 355-365 (2012).

\section{Author contributions}

All authors contributed equally.

\section{Competing interests}

The authors declare no competing interests.

\section{Additional information}

Correspondence and requests for materials should be addressed to D.I.U.

Reprints and permissions information is available at www.nature.com/reprints.

Publisher's note Springer Nature remains neutral with regard to jurisdictional claims in published maps and institutional affiliations. 
(c) (i) Open Access This article is licensed under a Creative Commons Attribution 4.0 International cc) License, which permits use, sharing, adaptation, distribution and reproduction in any medium or format, as long as you give appropriate credit to the original author(s) and the source, provide a link to the Creative Commons licence, and indicate if changes were made. The images or other third party material in this article are included in the article's Creative Commons licence, unless indicated otherwise in a credit line to the material. If material is not included in the article's Creative Commons licence and your intended use is not permitted by statutory regulation or exceeds the permitted use, you will need to obtain permission directly from the copyright holder. To view a copy of this licence, visit http://creativecommons.org/licenses/by/4.0/.

(C) The Author(s) 2021 